\title{
BARDA funds vaccine makers aiming to phase out eggs
}

The US government handed out contracts worth potentially more than $\$ 100$ million to boost innovative technologies that can deliver vaccines in large quantities — and fast—as part of a $\$ 1.9$ billion initiative to protect Americans from biologic threats of the future. The Biomedical Advanced Research and Development Authority (BARDA) has awarded money to eight firms engaged in creative ways to make vaccines against naturally occurring diseases, such as the H1N1 influenza, which was pandemic last year, and others it views as potential bioterrorist weapons. The goal, Kathleen Sebelius, Department of Health and Human Services (HHS) secretary says, is to create "nimble, flexible capacity to produce medical countermeasures rapidly in the face of any attack or threat."

Contract winners announced in September (Table 1) include VaxDesign, Novartis partnered with Synthetic Genomics Vaccines, the nonprofits PATH (Program for Appropriate Technology in Health) and the Infectious Disease Research Institute, Pfenex, Rapid Micro Biosystems, Emergent Biosolutions, 3M and Northrop Grumman Security Systems.

BARDA's push to make the vaccine development and production process move beyond half-century-old systems that rely on fertilized eggs to culture most vaccines has been several months in gestation. In August, two reports looked at the US's ability to produce vaccines quickly and efficiently and came away holding their noses. "The closer we looked at the countermeasure pipeline, the more leaks, choke points and dead ends we saw. In this age of new threats, we aren't generating enough new products," said Sebelius

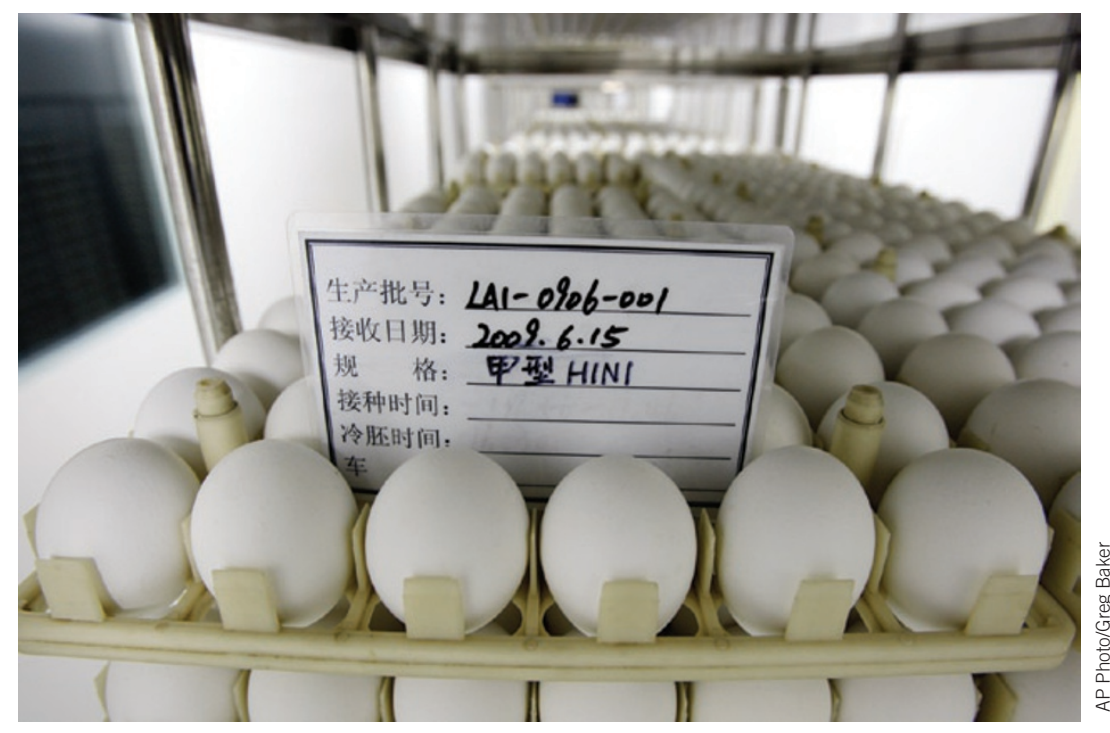

A half-century-old technology. Fertilized eggs were used to produce a vaccine for the H1N1 flu virus at the Sinovac plant in Beijing during the 2009 outbreak.

at a press conference on August 19 during which both reports were presented.

The first report, The Public Health Emergency Medical Countermeasures Enterprise Review (https://www.medicalcountermeasures.gov/ documents/MCMReviewFinalcover-508. pdf), commissioned by the HHS called for modernization and speed-up of the regulatory procedures, the development of more flexible vaccine manufacturing processes to allow more than one product to be produced at the same facility, and an upgrade and modernization of everything related to rapid influenza vaccine production. Nearly $\$ 2$ billion was put aside to reach the report's goals.
More quantitative was the President's Council of Advisors on Science and Technology's (PCAST) report entitled Reengineering the Influenza Vaccine Production Enterprise to Meet the Challenges of Pandemic Influenza (http://www.whitehouse.gov/sites/ default/files/microsites/ostp/Influenza $\% 20$ Vaccinology.pdf). It outlines every stumbling block to speeding up vaccine development but more significantly lists how much time could be saved by adapting improvements already in the pipeline. The Influenza Vaccinology Working group, chaired by Eric Lander, director of the Broad Institute of Harvard and MIT in Cambridge, Massachusetts, and Harold

\section{Table 1 Vaccine manufacturers awarded BARDA contracts}

\begin{tabular}{|c|c|c|}
\hline Company/location & Project aims & Contract value \\
\hline $\begin{array}{l}\text { Novartis Vaccines and Diagnostics/ } \\
\text { Cambridge, Massachusetts }\end{array}$ & $\begin{array}{l}\text { Novartis Vaccines and Diagnostics will investigate techniques for the rapid development of optimized influ- } \\
\text { enza seed virus. }\end{array}$ & $\begin{array}{l}\sim \$ 24 \text { million } \\
\text { over three years }\end{array}$ \\
\hline $\begin{array}{l}\text { Pfenex/ } \\
\text { San Diego }\end{array}$ & $\begin{array}{l}\text { Pfenex will apply its Pfenex Expression Technology Platform to the development of optimized bioprocesses for } \\
\text { high-yield production of a stable candidate anthrax vaccine. }\end{array}$ & $\begin{array}{l}\sim \$ 18.8 \text { million } \\
\text { over three years }\end{array}$ \\
\hline $\begin{array}{l}\text { VaxDesign/ } \\
\text { Orlando, Florida }\end{array}$ & $\begin{array}{l}\text { VaxDesign will further develop its MIMIC platform, an in vitro human immune system mimetic designed to accel- } \\
\text { erate evaluation of candidate and stockpiled vaccine safety and effectiveness by supplementing animal testing. }\end{array}$ & $\begin{array}{l}\sim \$ 17.1 \text { million } \\
\text { over three years }\end{array}$ \\
\hline $\begin{array}{l}\text { Northrop Grumman Security Systems/ } \\
\text { Baltimore }\end{array}$ & $\begin{array}{l}\text { Northup will develop integrated diagnostic capabilities for rapid, high-throughput surveillance and molecular } \\
\text { diagnostics. }\end{array}$ & $\begin{array}{l}\sim \$ 9.8 \text { million } \\
\text { over one year }\end{array}$ \\
\hline $\begin{array}{l}\text { PATH/ } \\
\text { Seattle }\end{array}$ & $\begin{array}{l}\text { PATH will test multiple innovative formulation chemistries and strategies to increase the shelf life of influenza } \\
\text { vaccines, which has implications for the national vaccine stockpile as well as cold-chain requirements domes- } \\
\text { tically and in developing countries. }\end{array}$ & $\begin{array}{l}\sim \$ 9.4 \text { million } \\
\text { over three years }\end{array}$ \\
\hline $\begin{array}{l}\text { Infectious Disease Research } \\
\text { Institute (IDRI)/ } \\
\text { Seattle }\end{array}$ & $\begin{array}{l}\text { IDRI will develop and evaluate innovative adjuvant formulations to enhance influenza vaccine immunogenicity } \\
\text { and cross-protection to make them more effective against novel viral strains that may cause the next pandemic. }\end{array}$ & $\begin{array}{l}\sim \$ 8.5 \text { million } \\
\text { over three years }\end{array}$ \\
\hline $\begin{array}{l}\text { Rapid Micro Biosystems/ } \\
\text { Bedford, Massachusetts }\end{array}$ & $\begin{array}{l}\text { Rapid Micro Biosystems will develop methods for accelerated sterility testing. Together, these improvements could } \\
\text { shave weeks off the influenza vaccine manufacturing and product release schedule. }\end{array}$ & $\begin{array}{l}\sim \$ 6.8 \text { million } \\
\text { over three years }\end{array}$ \\
\hline $\begin{array}{l}\text { 3M/ } \\
\text { St. Paul, Minnesota }\end{array}$ & $\begin{array}{l}\text { 3M will develop integrated diagnostic capabilities for rapid, high-throughput surveillance and molecular } \\
\text { diagnostics. }\end{array}$ & $\begin{array}{l}\text { \$6 million } \\
\text { over two years }\end{array}$ \\
\hline
\end{tabular}




\section{Vaccine makers' immunity questioned in court}

The US Supreme Court has begun considering how much liability vaccine makers have if the side effects of their products are believed to have injured or killed someone. The case was brought against Wyeth (now merged with Pfizer of New York) by parents of Hannah Bruesewitz, who in 1992 began suffering seizures and developmental problems after being given the combined Corynebacterium diphtheriae toxoid/Clostridium tetani toxoid/ polio (DTP) vaccine against diphtheria, tetanus and pertussis (whooping cough). A few years later, DTP was removed from the market and replaced by a vaccine with fewer side effects. The Bruesewitzes believed their daughter's injuries were avoidable because Wyeth should have put a product with fewer side effects on the market earlier.

What is most notable about the Bruesewitz $v$. Wyeth case, which was argued on October 12 in Washington, DC, is that many in the US drug industry had believed that the issue had been completely resolved with the adoption in 1986 of the National Childhood Vaccine Injury Act. The act set up a Vaccine Court to adjudicate claims of injury on a nofault basis and pay successful claimants with money generated from a tax on vaccines. The Vaccine Act was put into effect because of a fear at the time that lawsuits claiming 'design defects' would force companies to stop making vaccines. Accordingly, the act says suits cannot be filed against manufacturers "if the injury or death resulted from side effects that were unavoidable, even though the vaccine was properly prepared and was accompanied by proper directions and warnings."

There is a back door to the law that allows families to go to a federal court if they lose in Vaccine Court or they don't like the amount of its judgment. However, those suits are governed by the Vaccine Act, too.

But neither the Vaccine Court nor a lower US federal court accepted the Bruesewitzes' argument that their daughter's injuries could have been avoided by the manufacturer. However, the justices found the wording in the Act, and especially its use of the word "unavoidable" quite confused. Justice Stephen Breyer remarked "it's pretty hard to say the word unavoidable means avoidable." A final judgment is expected in early spring of 2011.

\section{Stephen Strauss}

Varmus, then at the Memorial Sloan-Kettering Cancer Center, also estimates the time it would take before these changes could be instituted.

From rapid sterility testing, to accelerated virus seed production and improved adjuvants, each advance could slice several weeks off the time for the first dose to reach the market. The PCAST committee members believed these changes individually could be put in place within 1 to 3 years. To change egg-based vaccine production systems for alternative cell or recombinant DNA platforms would require longer-up to a decade-to reach market penetration.

BARDA's R\&D money will help push a broad swath of potentially game-changing new technologies, but deputy assistant secretary of BARDA, Robin Robinson, admits that it doesn't cover the gamut of vaccine innovations in development. In particular, Robinson points to efforts to grow vaccines in plants and insect cells. Some of these projects are being funded by other US government agencies, most notably the Defense Advanced Research Project Agency, which is supporting four tobaccobased vaccine production platforms.

In plants, the process is quicker than in eggs. Andy Sheldon, president and CEO of Medicago of Quebec City, Canada, says "it takes five weeks to grow the tobacco, the plants start expressing the protein in five days, and then it takes two days to purify the VLPs [virus-like particles]." He compares this to the six months egg-based vaccine production takes. Medicago is entering phase 2 clinical trials with its plant-derived flu vaccine.

Plant-based production is cheaper too. The manufacturing facilities Medicago plans for Raleigh, North Carolina, will cost \$25 million to build, a far smaller investment than the $\$ 250$ million required for an egg-based production plant and the $\$ 1$ billion that Novartis recently spent on a new Holly Springs, North Carolina facility. If approval is granted, it will become the first facility in the United States licensed to use mammalian cells to produce flu vaccines and is expected to be operational in 2013.

A seasonal influenza vaccine, FluBlok, produced in insect cell culture, could be on the market next year. Protein Sciences of Meriden, Connecticut, received a BARDA contract in 2009 to use cells from fall armyworm (Spodoptera frugiperda) with a baculovirus system to generate influenza VLPs. Protein Science's president and CEO, Manon Cox, says it takes about two months from virus discovery to vaccine production using insect cells for production. It is also cheaper than egg-based vaccine manufacturing. "Licensed vaccines cost approximately $\$ 1$ a dose to make the active ingredients. Our estimates are that we can make three times more product for that price," claims Cox. Protein Sciences is waiting for US Food and Drug Administration approval of FluBlok.

Pfenex, too, says its technology is nearing the market. Last year, the Defense Threat Reduction Agency provided the company with a DNA sequence of an unknown antigen and challenged them to develop both a production strain and a high-speed, high-quality, low-cost, antigen-production process. In conjunction with partner organizations, Pfenex used its screening technology to do this within 42 days. And there were cost savings. "If you scaled up to production levels, the antigen can be produced for $\sim 50$ cents per dose," says Patrick Lucy, Pfenex's vice president of business development.

But the issue that looms largest in the push to modernize and speed up vaccine development relates to the business end of things. How are these innovative technologies going to fit into an existing vaccine marketplace thatinfluenza pandemics and potential terrorist bio-attacks aside-generally satisfies the world's vaccine needs?

For example, the PCAST report pointed out that although the Novartis cell culture facility was likely to generate annual profits of $\$ 30$ million, it "would take over 30 years to recover the [ $\$ 1$ billion] investment in nominal dollars (leaving aside the need for a return on investment)."

Protein Science's Cox argues this naturally leads vaccine manufacturers, using egg-based technologies, to resist any change. "They are not going to easily let that [advantage] be taken away by a new technology in which their learning curve is going to be as steep as anybody's else's," she says. Rafick-Pierre Sékaly, co-director and scientific director of the Vaccine and Gene Therapy Institute of Port St. Lucie, Florida, concurs. "The president and the committee can make all the recommendations they want but if the big vaccine makers say it is too costly or there is too much $R \& D$, then changes are going to be treated not as a solution but as an added burden.”

On this point, BARDA's Robinson says, "we understand, and that is why we are pushing things that will definitely benefit all vaccines, including eggs." Indeed, in October BARDA awarded Sanofi Pasteur of Lyon, France, a 3-year, \$57 million contract to make more fertilized eggs available for vaccine production on a year-round basis.

Stephen Strauss, Toronto 